\begin{tabular}{ll}
\hline \hline MINING AND METALLURGY INSTITUTE BOR & ISSN: 2334-8836 \\
& UDK: 622 \\
\hline \hline
\end{tabular}

UDK: $622.33(045)=20$

DOI:10.5937/MMEB1303081V

Nebojša Vidanović, Rade Tokalić, Ljubinko Savic ", Suzana Lutovac ${ }^{*}$

\title{
JUSTIFICATION OF RENEWED COAL EXPLOITATION FROM THE DEPOSIT "BAJOVAC ${ }^{* * * *}$
}

\begin{abstract}
Coal presents the basic energy potential of the Republic of Serbia. More than half of electric energy production in our country comes from this resource. This causes a need for activation the new seams of raw material which are potentially exploitable. This work presents an extract from the research results, published within the Project TR 33029 "Study of Possibilities for Valorization the Remaining Coal Reserves with a View to Provide the Stability of Energy Sector of the Republic of Serbia", financed by the Ministry of Education and Science. This work treated the problems of future coal exploitation from the West Morava Basin, with special review to the activation of the closed mine "Bajovac".

Keywords: coal, exploitation, deposit, seam, capacity, method
\end{abstract}

\section{GENERAL DATA ON DEPOSIT AND ITS PREVIOUS EXPLOITATION}

The West Morava coal seam presents the unique coal bearing location in the area of Bresnica - Tavnik - Ladjevci. The mine "Bajovac" is located in the north-east part of the Basin (Cacak - Kraljevo). Total surface of the Basin is $1000 \mathrm{~km}^{2}$, while the production coalbearing area of the mine "Bajovac" has surface of $1.5 \mathrm{~km}^{2}$.

For many years, the coal has been exploited in the area of Bresnica - Tavnik Ladjevci from four coal mines, as well as: "Bresnica", "Voljace", "Tavnik" and "Bajovac".

\subsection{LOCATION AND SPREADING}

The mine "Bajovac" is located near the village of Ladjevac in the vicinity of the

town of Kraljevo. Based on data from exploration drill holes in the panon-pontic coal series, the reserves of two coal zones were determined the upper with two coal seams and the lower with five, from which only upper one has the economic value.

In the upper coal zone, the highest coal seam is marked as the upper-roof $A_{1}$ seam with the average thickness of 6-8 $\mathrm{m}$ of pure coal in the seam, with barren interseams of $15 \mathrm{~m}$. The seam $A_{1}$ presents the main coal seam, which only was in exploitation in the mentioned pit field. It has a regular development in largerarea and it is mined quite steeply in the direction of southwest under angle of $49^{\circ}$, regarding that in the vicinity of Mrcajevci-Ladjevci cleavage falling angle

\footnotetext{
* University of Belgrade, Faculty of Mining and Geology, Djusina 7, 11000 Beograd, Srbija, e-mail:vidanovic@rgf.bg.ac.rs, tokalic@rgf.bg.ac.rs, lutovac@rgf.bg.ac.rs

** FTS Kosovka Mitrovica

*** This paper was made as the result of the Project No. 33029 Study of Possibilities for Valorization the Remaining Coal Reserves with a View to Provide the Stability of Energy Sector of the Republic of Serbia", financed by the Ministry of Education, Science and Technological Development of the Republic of Serbia.
} 
rises up to $85^{\circ}$, so it lies in different depths in the eastern part about $30 \mathrm{~m}$, and in the western part about $400 \mathrm{~m}$. The lower layer was never under exploitation. Exploitation of coal in the mine "Bajovac" started in 1958. And with high efforts, it was maintained by the end of 1986 . Production of coal was low, in the interval from 7,000 to $17,000 \mathrm{t}$ annually, although conditions for mining in this pit are very favorable, and conditions of coal placement and entire climate did not enable better results.

\subsubsection{Tectonic Review of the Basin}

Based on geological and geophysical testing in the West Morava Basin, intensive tectonic movements were noticed, represented by cleavages of different intensity. The main role in forming of the West Morava valley had the longitudinal the West Morava fault of high intensity with direction SE-NW.

Due to strong tectonic intensity, a part of depression sunk in depth, so the thickness of Neogene sediments in that part is the largest. According to data of exploration drilling in the area of the village of Katrge, the thickness of Neogene sediments in the lowered part is $1910 \mathrm{~m}$, and in the south raised part is about $1200 \mathrm{~m}$, so the jump along this cleavage is about $700 \mathrm{~m}$, meaning that north part is much more lowered.

Little more to the north, parallel to the previous one, the 'Mrcajevci-Ladjevci' fault is stretched, which on length of over 20 $\mathrm{km}$ cuts down the productive series, so across its length south wing together with coal seams has lowered for about $350 \mathrm{~m}$. This fault has a special significance for exploitation, because it is possible to perform excavation by mining works only to its border in all coal areas.

Between these two faults, the medium parts went very low, so one secondary tectonic trench is formed inside the valley, going in length to the east outside of the West Morava Basin to the Krusevac Basin.
Besides mentioned longitudinal faults, several cross faults of significantly lower intensity were determined in the north and north-east part of Basin, inside which the coal series is shared into blocks. So, the existence of faults was determined along the Dicina River, then the Banjska River and the Bresnicka River and others.

Along these faults, some blocks significantly went lower in depth, and some remained to stick out like horsts, so later due to erosion part of roof and upper coal zone were taken away, and in some places the coal seam too.

\subsection{RAW MATERIAL BASE}

\subsubsection{Limitation of the Coal Bearing Area}

The coal bearing area of the West-Morava Basin includes the north-east part, and it is separated in the area Bresnica - Tavnik Ladjevci. That is where the upper roof coal seam was exploited for many years in the mining districts: Bresnica, Voljavca, Tavnik and Bajovac, with surface area of $2.8 \mathrm{~km}^{2}$.

The former mining district of the mine "Bajovac" which has surface of app. 1.3 $\mathrm{km}^{2}$, in the east side is limited with offspring zone of direction NW-SE, while the west lower border is separated by MrcajevciLadjevci fault that cuts the coal seam in two parts, so the lower west wing went down about $350 \mathrm{~m}$. Southeast border is profiled line of drill holes T- 8 and T-12 where the coal seam of smaller thickness is determined, while the northwest border is old works of the earlier mines of Tavnik and Bajovac. By direction of stretching, the length of exploitation area is 900 to $1000 \mathrm{~m}$.

\subsubsection{Coal Reserves in the Mining Dis- trict of the Mine "Bajovac"}

Since coal reserves in the mine "Bajovac" are important for this work, the following Table 1 shows the reserves of this mining district. 
Table 1

\begin{tabular}{|c|c|c|c|}
\hline \multicolumn{4}{|c|}{ Geological reserves of upper $A_{1}$ coal seam in the mining district "Bajovac" ( $t$ ) } \\
\hline Category & Balance & Out of balance & Total \\
\hline A & $5,373,470$ & 137,280 & $5,510,750$ \\
\hline B & $2,039,550$ & - & $2,039,550$ \\
\hline Total A+B & $7,413,020$ & 137,280 & $7,550,300$ \\
\hline \multicolumn{4}{|c|}{ Geological reserves of lower $B_{2}$ coal seam in the mining district "Bajovac" ( $\left.t\right)$} \\
\hline $\mathbf{A}$ & - & - & - \\
\hline B & $2,704,970$ & - & $2,704,970$ \\
\hline $\mathrm{C}_{1}$ & 168,880 & - & 168,880 \\
\hline Total $A+B+C_{1}$ & $7,413,020$ & - & $7,550,300$ \\
\hline Total Bajovac & $10,286,870$ & 137,280 & $10,424,150$ \\
\hline
\end{tabular}

\subsubsection{Geological Characteristics of the Coal Seam and Associated Rocks}

Coal bearing field of the mining district of the mine "Bajovac" was explored with seven exploration drill holes, while two cuts, $\mathrm{k}+115.6 \mathrm{~m}$ were opened by the former exploration works. Drill holes are located on parallel profile lines, in distances, per stretching of coal seams of 250 to $600 \mathrm{~m}$, and per fall from 200 to $250 \mathrm{~m}$. All mining premises are also oriented per stretching.

On the basis of received data, it was determined that two coal zones are present in this coal bearing field, but in economic view, only the upper zone is significant with two regular developed coal seams, separated as $A_{1}$ and $B_{2}$, with space development, similar thickness and continuous quality. Distance between these two layers is in the range from 50 to $60 \mathrm{~m}$.

In the lower zone, the coal seams are irregular with small thickness, poor quality, so they do not have an economic value from the mining point of view.

The roof $\mathrm{A}_{1}$ of coal seam has regular development in larger space on the area of Bresnica, Tavnik, Bajovac and Ladjevci. The real thickness of coal seam in the mining district of the mine Bajovac is in the range from $2.60 \mathrm{~m}$ to $11.90 \mathrm{~m}$, or on the average of $8.5 \mathrm{~m}$. Coal seam is ho mogenous with uniform composition of xylite-vitrite type, with scattered seamsof detrital (clay-marl) type.

Coal seam stretches quite steeply in the southwest direction with angle of about $49^{\circ}$, while in the vicinity of Mrcajevci-Ladjevci fault falling angle increases up to $85^{\circ}$ and lies down on different thicknesses, in the east part about $30 \mathrm{~m}$, and in the west part about $400 \mathrm{~m}$. Direct bottom and roof part of coal seams are coalish sebaceous clays and marl gray stratified clays.

Bottom $\mathrm{B}_{2}$ coal seam in the frame of this coal field is regularly developed and it lies beneath the roof one in the distance of 50 to $60 \mathrm{~m}$. It is separated by dirt bands, and divided into three thinner coal seams. Its total thickness with dirt bands is from $3.0 \mathrm{~m}$ to $12.0 \mathrm{~m}$, and without dirt bands is from 1.5 to $5.3 \mathrm{~m}$. Dirt bands are made of coalish and gray thin layered clays.

Generally, it also stretches, as the previous one towards southwest, under approximate angle, so it is stretched from 20 $\mathrm{m}$ on the east to $480 \mathrm{~m}$ on the west. Roof level and bottom level are made of coalish sebaceous and marlish clay and marl itself.

This coal layer has never been exploitted, so all data about it are based on the 
exploration drill holes and offsprings on the surface. It was entered from the shaft "Strmuzak" at k + $165 \mathrm{~m}$, but there were no more mining works on the seam.

\subsubsection{Quality of Coal}

Testing the coal quality was done in the laboratory of the Mining Institute - Zemun, so there are enough data for review of coal quality and its wide application.

Coal from the mine "Bajovac" has good physical characteristics, because roof $A_{1}$ seam is quite compact and sinewy, although there are smaller lens of friable and soft earthy-detrital coal. It has band structure, partially lenticular, brown to dark color, dark scratch, slope and lenticular stratification, irregular fracture.

Coal loses moisture during standing and storage, so the total loss of moisture under longer storage is up to $24 \%$, therefore it cannot be stored for a long period of time, except under special conditions.
Petrographic tests showed that coal belongs to the vitrite-clarite and clarite type, and it is made of vitrite, clarite, durite and fasite. Due to quite low level of gelification, wooden components of vitrite prevails, and they amount from 11 to $35 \%$ and clarite from 37 to $70 \%$, while the level of vitrite participates with smaller amount from 3 to $10 \%$.

Inorganic impurities in coal are singenetic terigene ingredients, presented by coalish clays from 9 to $61 \%$, and from authigenic minerals in coal there are pyrites, marcasite, and siderite, with highest participation of pyrites, from 1 to $5 \%$. From epigenetic ingredients in coal, only plaster is present.

Based on these petrographic analyses, coal from the mine „Bajovac" belongs to the group of hard brown-lignite coals.

Laboratory tests of chemical-physical characteristics of raw coal from roof $\mathrm{A}_{1}$ seam, taken from the pit of the mine "Bajovac", have shown the following results:

\section{Technical analysis:}

- Moisture

- Ash

- S total

- $\mathrm{S}$ in ash

- Coke

- C-fix

- Combustible

- Volatile

- DTE

- GTE
$35.30 \%$

$16.28 \%$

$1.65 \%$

$0.59 \%$

$57.84 \%$

$21.36 \%$

$48.42 \%$

$26.86 \%$

$12.050 \mathrm{~kJ} / \mathrm{kg}$

$13.574 \mathrm{~kJ} / \mathrm{kg}$

Elemental analysis:

- Carbon

- Hydrogen

- Oxygen + Nitrogen

- $\mathrm{S}$ combustible

Laboratory tests of chemical-physical characteristics of raw coal from roof $\mathrm{B}_{2}$ seam, taken from works in the mining districtt Tavnik-Strmuzak have shown the following results: 


\section{Technical analysis:}

- Moisture

- Ash

- S total

- $\mathrm{S}$ in ash

- Coke

- C-fix

- Combustible

- Volatile

- DTE
$36.15 \%$

$15.25 \%$

$1.49 \%$

$0.76 \%$

$38.83 \%$

$23.58 \%$

$48.60 \%$

$25.02 \%$

$12,050 \mathrm{~kJ} / \mathrm{kg}$

\section{Elemental analysis:}

$\begin{array}{lr}\text { - Carbon } & 70.20 \% \\ \text { - Hydrogen } & 5.66 \% \\ \text { - Oxygen + Nitrogen } & 22.41 \% \\ \text { - S combustible } & 1.50 \%\end{array}$

It could be seen from the present data that data for both seams are similar, what for coals from these two seams means that they are practically the same.

As another data from the literature, there is a successful attempt to dry coal with steam under pressure of $20 \mathrm{~atm}$. According to data, this treatment gave the excellent results and that the fuel of very good quality was obtained:

$\begin{array}{lr}\text { - Moisture } & 12.70 \% \\ \text { - Ash } & 14.80 \% \\ \text { - S total } & 1.30 \% \\ \text { - S in ash } & 0.70 \% \\ \text { - Coke } & 46.80 \% \\ \text { - C-fix } & 32.00 \% \\ \text { - Combustible } & 72.40 \% \\ \text { - Volatile } & 40.40 \% \\ \text { - DTE } & 18.130 \mathrm{~kJ} / \mathrm{kg} \\ \text { - Carbon } & 50.00 \% \\ \text { - Hydrogen } & 4.20 \%\end{array}$

Also, the experiments of dry distillation and gasification were carried out, and it was determined that coal from this basin could be used for production of metallurgical products, which in quality

completely satisfies the needs of the metallurgy.

Coal could also be successfully used for production of high-caloric gas for industrial and thermal needs. 


\section{TECHNICAL-TECHNOLOGICAL CONDITIONS OF EXPLOITATION}

\subsection{PRODUCTION CAPACITY}

In calculation the production capacity in the pit of the mine "Bajovac", the following facts have to be considered:

1. Production requested by investors is 200.000 t.c.c. (tons of commercial coal);

2. For coal excavation, both coal seams have to be foreseen;

3. Liquidation of protection pillars of previous opening premises will be performed at the first horizon;

4. Four excavation methods would be applied in the pit, and only one of them was used in this mine.

\section{Production capacity at the I horizon $(k+240-k+160 m)$}

In the roof coal seam $\mathrm{A}_{1}$ at the I horizon only $112,000 \mathrm{t}$ of geological reserves or cca 100.000 t.c.c. will be included. Coal reserves will be in liquidation and the excavation method will be applied that was already used in this pit, and that is the modified pillar-chamber method. In such conditions, the annual production could not be expected at the level larger than 50,000 t.c.c.

Regarding to the characteristics of bottom coal seam (thickness of coal seam from 3 to $12 \mathrm{~m}$ with coal participation in seam (in three thin seams) of $50 \%$, i.e. 1.5 to $6.0 \mathrm{~m}$, due to larger quantity of waste in the excavated coal in this seam, the production from this seam must not exceed $30 \%$ of total production, so in this phase, the production of total 20,000 t.c.c. could be planned.

Total production at the I horizon will amount 70,000 t.c.c./year in the first two years. This dynamics of production will lead to imbalance, because after two years all coal in the roof seam of this horizon will be excavated, with only $10 \%$ of reserves in the bottom one. This imbalance fill be fixed in later exploitation, when the production in the roof seam will be significantly increased.

\section{Production capacity at the II horizon $(k+160-k+80 \mathrm{~m})$}

In the roof coal seam $\mathrm{A}_{1}$ at the II horizon $829,000 \mathrm{t}$ of geological reserves or cca 790,000 t.c.c. will be included, but the excavation will be organized with one sub-level which would divide this sub-level per altitude in two equal parts. In the upper sublevel, cca 340,000 t.c.c would be. From this amount in the south wing, cca 130,000 t.c.c. would be located, and the excavation method that was already in use in this mine, would be applied. Yearly capacity would be 65,000 t.c.c. and the excavation would last for two years. At the same time, the excavation by friction pillars would be introduced in the north wing, in the amount of 210.000 t.c.c. With capacity of over 80.000 t.c.c., the excavation would last just over 2.5 years. A part of coal reserves will be in liquidation of the previous protection pillars of opening premises (cca 40,000 t.c.c.) and the excavation method that was already in use in this pit would be applied, and that is the modified pillar-chamber method. In these conditions, the yearly production at the level larger than 50,000 t.c.c. could not be expected, so in the upper sub-level, the excavation would last for 2.5 years, and cca 380,000 t.c.c. would be excavated. In the second sub-level, the production would be cca 400,000 t.c.c. Since in this part there is no liquidation of the old protection pillars, this sub-level would be divided in two asymmetric wings, in the south in length of $420 \mathrm{~m}$ and in the north north in length of 
$510 \mathrm{~m}$. From total quantities of reserves in the south cca 180,000 t.c.c. would be, where the excavation method that was already in use in this pit would be applied. Yearly capacity would be 65,000 t.c.c. and the excavation would last cca 3 years. At the same time, the excavation by friction pillars would be introduced to the north wing in the amount of cca 220.000 t.c.c. With capacity of 80.000 t.c.c., the excavation would last also cca 3 years, and cca 400.000 t.c.c. would be excavated.

As it was said that production from the bottom seam must not exceed $30 \%$ from total production, in this phase yearly production of 234.000 t.c.c. or cca 42.000 t.c.c. could be planned.

Total production at the II horizon will amount 167,000 t.c.c. per year in 5.5 years. This dynamics of production would correct inequality, regarding that after 5.5 years about 260,000 t.c.c. would be excavated in the bottom seam of the I horizon and cca 40.000 t.c.c. in the bottom seam of the II horizon.

\section{Production capacity at the III horizon $(k+80-k+0 \mathrm{~m})$}

In roof coal seam $\mathrm{A}_{1}$ at the III horizon, $856,000 \mathrm{t}$ of geological reserves or cca 810.000 t.c.c. will be included. Coal reserves are in ideal position and after 5.5 years the modern excavation method could be introduced, i.e. the excavation by wide frontal mechanized complex. In these conditions, the yearly production at the level larger than 180,000 t.c.c. could be expected. Excavation would be carried out in the entire deposit in length of $940 \mathrm{~m}$ and it would last for 4.5 years or with the average advancing of front of $22 \mathrm{~m} / \mathrm{month}$.

Production from the bottom seam in this horizon also must not exceed $30 \%$ of total production, so in this phase the production of total 60,000 t.c.c. or 270,000 t.c.c. for 4.5 years could be planned, so a delay in excavation in the bottom seam for one entire horizon would be practically achieved.

\section{Production capacity at the IV horizon $(k+0-k-80 \mathrm{~m})$}

Semi-horizon (k-80 - k-100 m) - Liquidation

Excavation would be carried out in this semi-horizon in the roof seam using the modified pillar-chamber method with capacity of $2 \times 50,000$ t.c.c., two-wings, and it would last cca 1.5 years. Regarding that with starting the excavation in this semi-horizon about $450,000 \mathrm{t}$ would be left in the roof seam, the same would be excavated in that period at the level of 30,000 t.c.c./year, so total production in this period would be 130,000 t.c.c..

The remaining 400,000 t.c.c. in the bottom seam could be excavated, if the market would be found or if some other mines of this basin would be opened. Independently, it could be possible to organize the excavation at the level of $2 \times 40,000$ t.c.c., also twowings, in time of 5 years.

\subsection{PRODUCTION DYNAMICS AND LIFETIME}

In accordance to the suggested technical solution, the exploitation of this deposit would be carried out for 22 years. Yearly production in this period would be of 70,000 t/year in the first and second year, then it would be increased successively in the following six years and, in the ninth year, it could be possible to reach maximum capacity of 240,000 t/year which would be maintained in the following seven years. In the last six years, the production would be gradually decreased due to the deposit structure, and in the last year, it would amount $40,000 \mathrm{t} /$ year. 


\section{CONCLUSION}

This work presents an extract from the research results, published within the Project TR 33029 "Study of Possibilities for Valorization the Remaining Coal Reserves with a View to Provide the Stability of Energy Sector of the Republic of Serbia", financed by the Ministry of Education and Science. This work treated the problems of future coal exploitation from the West Morava Basin, with special review to the activation of the closed mine "Bajovac".

The basic idea that was a guide to the authors was to activate this deposit as a replacing capacity for the Ibar mines until finding the adequate solutions. For analysis of possibilities the coal exploitation from this deposit, all available technical documentation was used with simultaneous consultation of all relevant experts dealing with these problems.

Very detailed techno-economic analysis of the deposit "Bajovac" unequivocally has determined a justification of its reopening. The basic technical solutions were suggested in the frame of research, according to this Project, for opening, excavation methods, necessary work force per number and struc

ture and necessary equipment. Economic analysis of this investment, which included the costs, market prices, and other relevant indicators also gave the positive results, therefore generally this project could get a positive evaluation.

\section{REFERENCES}

[1] N. Vidanovic et al., Justification Study of Exploitation Deposits "Cerje" of Despotovac Coal Basin and "Bajovac" of The West Morava' Coal Basin, FMG Belgrade, 2011; (in Serbian)

[2] P.Nikolic, D. Dimitrijevic, Coal of Yugoslavia, Pronalazastvo, Belgrade 1990, (in Serbian)

[3] N. Vidanovic, R. Tokalic, S. Mitic, Justification of Coal Explitation from Deposit "Cerje - Jovacko Polje, Journal "Underground Works", number 221, ISSN 03542904, p. 9-15, FMG Belgrade, 2012. (in Serbian) 


\begin{tabular}{ll}
\hline \hline INSTITUT ZA RUDARSTVO I METALURGIJU BOR & ISSN: 2334-8836 \\
& UDK: 622 \\
\hline \hline
\end{tabular}

\author{
Nebojša Vidanović, Rade Tokalić, Ljubinko Savić*, Suzana Lutovac*
OPRAVDANOST PONOVNE EKSPLOATACIJE UGLJA IZ LEŽIŠTA „BAJOVAC““***

\begin{abstract}
Izvod
Ugalj predstavlja osnovni energetski potencijal Republike Srbije. Više od polovine električne energije koja se proizvede u našoj zemlji je iz ovog resursa. To uslovljava potrebu aktiviranja novih potencijalno eksploatabilinh ležišta ove sirovine. Ovaj rad predstavlja izvod iz rezultata istraživanja koja su objavljena u okviru projekta TR 33029 "Izučavanje mogućnosti valorizacije preostalih rezervi uglja u cilju obezbeđenja stabilnosti energetskog sektora Republike Srbije" a koje finasira Ministarstvo prosvete $i$ nauke. U njemu je tretirana problematika buduće eksploatacije uglja iz Zapadno-moravskog basena, sa posebnim osvrtom na aktiviranje zatvorenog rudnika "Bajovac".

Ključne reči: ugalj, eksploatacija, ležište, sloj, kapacitet, metoda
\end{abstract}

\section{OPŠTI PODACI O LEŽIŠTU I NJEGOVOJ DOSADAŠNJOJ EKSPLOATACIJI}

Zapadno - moravski ugljeni sloj sačinjava jedinstveni ugljonosni lokalitet na područiju Bresnica - Tavnik - Lađevci. Rudnik "Bajovac", se nalazi u severoistočnom delu basena (Čačak - Kraljevo). Ukupna površina basena iznosi $1000 \mathrm{~km}^{2}$, dok produktivno ugljonosno područije rudnika "Bajovac" zahvata prostor od $1,5 \mathrm{~km}^{2}$.

Dugi niz godina ugalj je eksploatisan $\mathrm{u}$ područiju Bresnica - Tavnik - Lađevci sa četiri ugljenokopa i to: "Bresnica", "Voljače", "Tavnik" i "Bajovac".

\subsection{POLOŽAJ I RASPROSTRANJENJE}

Rudnik "Bajovac" nalazi se kod sela Lađevac blizu Kraljeva. Na bazi podataka iz istražnih bušotina u panonsko-pontijskoj ugljonosnoj seriji utvrđene su dve ugljonosne zone, gornja sa dva ugljena sloja i donja sa pet, od kojih je samo gornja od ekonomske vrednosti.

U gornjoj ugljonosnoj zoni najviši ugljeni sloj označen kao gornji-krovinski $\mathrm{A}_{1}$ sloj ima prosečnu debljinu od 6-8 m čistog uglja u sloju, a sa jalovim proslojcima i do $15 \mathrm{~m}$. Sloj $A_{1}$ pretstavlja glavni ugljeni sloj, koji je do sada jedini bio u eksploataciji u navedenim revirima. Ima regularno razviće

\footnotetext{
* University of Belgrade, Faculty of Mining and Geology, Djusina 7, 11000 Beograd, Srbija, e-mail:vidanovic@rgf.bg.ac.rs, tokalic@rgf.bg.ac.rs, lutovac@rgf.bg.ac.rs

** FTN Kosovska Mitrovica

** Ovaj rad predstavlja izvod iz rezultata istraživanja koja su objavljena u okviru projekta TR 33029 "Izučavanje mogućnosti valorizacije preostalih rezervi uglja u cilju obezbeđenja stabilnosti energetskog sektora Republike Srbije” a koje finasira Ministarstvo prosvete, nauke i tehnološkog razvoja Republike Srbije.
} 
na većem prostoru i zaleže dosta strmo u pravcu jugozapada pod uglom od $49^{\circ}$, stim što u blizini mrčajevačko - lađevačkog raseda padni ugao se povećava i do $85^{\circ}$, tako da leži na različitim dubinama $i$ to $u$ istočnom delu oko $30 \mathrm{~m}$, a u zapadnom na oko $400 \mathrm{~m}$. Podinski sloj nije nikada eksploatisan. Eksploatacija uglja u rudniku "Bajovac" otpočela je 1958. godine i uz velike napore održavala se do kraja 1986. godine. Proizvodnja uglja bila je skromna i kretala se godišnje od 7.000 do 17.000 t, mada su uslovi za rudarenje u ovoj jami veoma povoljni, tadašnji uslovi plasmana uglja i celokupna klima nisu omogućavali bolje rezultate.

\subsubsection{Tektonski prikaz basena}

$\mathrm{Na}$ osnovu geoloških i geofizičkih ispitivanja u zapadno moravskom basenu uočeni su intezivni tektonski pokreti pretstavljeni rasedima različitog inteziteta. Glavnu ulogu u formiranju zapadno-moravske kotline imao je uzdušni "zapadnomoravski" rased, velikog stepena inteziteta, pravca pružanja JI-SZ.

Usled jake tektonske intezivnosti deo depresije je potonuo u dubinu, tako da je i debljina neogenih sedimenata $u$ tom delu najveća. Prema podacima istražnog bušenja u ataru sela Katrge debljina neogenih sedimenata u spuštenom delu je $1910 \mathrm{~m}$, a u južnom izdignutom oko 1200 m, tako da je skok duž ovog raseda oko $700 \mathrm{~m}$, odnosno da je za toliko spušteno severno krilo.

Nešto severnije, paralelno sa prethodnim pruža se drugi mrčajevačko-lađevački rased, koji na dužini preko $20 \mathrm{~km}$ preseca produktivnu seriju, tako da je duž njega južno krilo zajedno sa ugljenim slojevima potonulo za oko $350 \mathrm{~m}$. Ovaj rased je od posebnog značaja za eksploataciju, jer se rudarskim radovima može vršiti otkopavanje samo do njegove granice u svim ugljonosnim područijma.

Između ova dva raseda, središnji delovi su duboko potonuli, tako da je unutar same kotline formiran jedan sekundarni tektonski rov, koji se prema istoku produžuje i van granica Zapadno moravskog basena $\mathrm{u}$ Kruševački basen.

Pored pomenutih uzdužnih u severnom i severoistočnom delu basena utvrđeno je prisustvo i nekoliko poprečnih raseda znatno manjeg inteziteta, kojima je ugljonosna serija iskomadana u blokove. Tako je utvrđeno postojanje raseda duž reke Dičine, zatim Banjske i Bresničke reke i drugi.

Duž ovih raseda neki blokovi su znatno potonuli u dubinu, a neki su ostali visoko da strče u vidu horstova, tako da je kasnije erozijom odnešen deo krovine i gornja ugljenosna zona, a mestimično i ugljeni slojevi.

\subsection{SIROVINSKA BAZA}

\subsubsection{Ograničenje ugljonosnog prostora}

Ugljonosno područije zapadno moravskog ugljenog basena zahvata severoistočni deo, a izdvojen je u predelu Bresnica - Tavnik - Lađevci. U njemu je gornji krovinski ugljeni sloj eksploatisan dugi niz godina $\mathrm{u}$ revirima: Besnica, Voljavča, Tavnik i Bajovac, zahvativši površinu cca $2,8 \mathrm{~km}^{2}$.

Nekadašnji Revir rudnika "Bajovac" koji zahvata površinu od cca $1,3 \mathrm{~km}^{2}$, ograničen sa istočne strane izdanačkom zonom pravca pružanja SZ-JI, dok je zapadna donja granica izdvojena mrčajevačko-ladjevačkim rasedom, kojim je ugljeni sloj presečen na dva dela, tako da je donje zapadno krilo potonulo oko $350 \mathrm{~m}$. Jugoistočnu granicu čini profilska linija bušotina T-8 i T-12, gde je utvrđen ugljeni sloj manje debljine, dok severozapadnu granicu čine stari radovi ranijih rudnika Tavnik i Bajovac. Po pružanju dužina eksploatacionog prostora iznosi 900 do $1000 \mathrm{~m}$.

\subsubsection{Ugljene rezerve $u$ reviru rudnika "Bajovac"}

Kako su za ovaj rad bitne rezerve uglja rudnika „Bajovac“ u sledećoj tabeli prikazaće se rezerve ovog revira. 
Tabela 1.

\begin{tabular}{|c|c|c|c|}
\hline \multicolumn{4}{|c|}{ Geološke rezerve gornjeg $A_{1}$ ugljenog sloja u reviru jame "Bajovac" (t) } \\
\hline Kategorija & Bilansne & Vanbilansne & Ukupne \\
\hline $\mathbf{A}$ & 5.373 .470 & 137.280 & 5.510 .750 \\
\hline B & 2.039 .550 & - & 2.039 .550 \\
\hline Ukupno A+B & 7.413 .020 & 137.280 & 7.550 .300 \\
\hline \multicolumn{4}{|c|}{ Geološke rezerve gornjeg $B_{2}$ ugljenog sloja u reviru jame "Bajovac" (t) } \\
\hline $\mathbf{A}$ & - & - & - \\
\hline B & 2.704 .970 & - & 2.704 .970 \\
\hline $\mathrm{C}_{1}$ & 168.880 & - & 168.880 \\
\hline Ukupno $A+B+C_{1}$ & 7.413.020 & - & 7.550 .300 \\
\hline Ukupno Bajovac & 10.286 .870 & 137.280 & 10.424 .150 \\
\hline
\end{tabular}

\subsubsection{Geološke karakteristike ugljenog sloja i pratećih stena}

Ugljonosno polje revira rudnika „Bajovac" istraženo je sa sedam istražnih bušotina, dok je nekadašnjim eksploatacionim radovima otvoreno da kote $\mathrm{k}+115,6 \mathrm{~m}$. Bušotine su locirane na paralelnim profilnim linijama, na rastojanjima, po pružanju ugljenih slojeva od 250 do $600 \mathrm{~m}$, a po padu od 200 do $250 \mathrm{~m}$. Sve rudarske prostorije orijentisane su takođe po pružanju.

Na bazi dobijenih podataka utvrđeno je da su u ovom ugljonosnom polju prisutne dve ugljonosne zone, ali je u ekonomskom pogledu značajna samo gornja zona, u kojoj se nalaze dva regularna razvijena eksploataciona ugljena sloja izdvojena kao $\mathrm{A}_{1} \mathrm{i}_{2}$, prostornog razvića, približne debljine i ujednačenog kvaliteta. Rastojanje između ova dva sloja kreće se od 50 do $60 \mathrm{~m}$.

U donjoj zoni ugljeni slojevi su neregularni, male debljine, veoma lošeg kvaliteta, tako da sa rudarskog gledišta nemaju praktičnu ekonomsku vrednost.

Krovinski $A_{1}$ ugljeni sloj ima regularno razviće na većen prostoru područija Bresnice, Tavnika, Bajovca i Lađevaca. Prava debljina ugljenog sloja u reviru polja Bajovac kreće se od 2,60 m do 11,90 m, odnosno u proseku od 8,5 m. Ugljeni sloj je homogen, ujednačenog sastava, ksilitski-

vitritskog tipa, sa mestimičnim proslojcima detruitusnog (glinovito-laporovitog) tipa.

Ugljeni sloj zaleže dosta strmo u pravcu jugozapada pod uglom od oko $49^{0}$, stim što se u blizini mrčajevačko lađevačkog raseda padni ugao povećava $\mathrm{i}$ do $85^{\circ}$ te leži na različitim dubinama i to u istočnom delu oko $30 \mathrm{~m}$, a u zapadnom na oko $400 \mathrm{~m}$. Direktnu podinu i krovinu ugljenog sloja čine ugljevite masne gline i laporovite sive uslojene gline.

Podinski $\mathrm{B}_{2}$ ugljeni sloj u okviru ovog ugljonosnog polja je regularno razvijen i leži ispod povlatnog na rastojanju od 50 do 60 m. Raslojen je jalovim proslojcima, tako da je podeljen u tri tanja ugljena sloja. Ukupna njegova debljina sa jalovim proslojcima kreće se od 3,0 do 12,0 m, dok bez proslojaka varira od 1,5 do 5,3 m. Jalovi proslojci jalovi proslojci su od ugljevitih i sivih tanko uslojenih glina.

Generalno takođe zaleže, kao i prethodni u pravcu jugozapada, pod približnim uglom, tako da se nalazi ovaj sloj kreću od $20 \mathrm{~m}$ na istoku do $480 \mathrm{~m}$ na zapadu. Krovinu i podinu ovog sloja je kao i kod povlatnog izgradjena od ugljevitih masnih i laporovitih glina i lapora. 
Ovaj ugljeni sloj nikada nije eksploatisan, pa se svi podaci o njemu baziraju na osnovu istražnih bušotina i izdanaka na površini. Iz okna „Strmužak“ u ovaj sloj ušlo se sa kote $k+165 \mathrm{~m}$, ali se nije dalje išlo rudarskim radovima po sloju.

\subsubsection{Kvalitet uglja}

Utvrđivanje kvaliteta uglja vršena su uglavnom u laboratoriji Rudarskog instituta - Zemun, tako da postoji dovoljno podataka za sagledavanje kvaliteta uglja i njegovu široku primenu.

Ugalj iz rudnika „Bajovac“ ima dobre fizičke osobine, jer je krovinski $A_{1}$ sloj prilično kompaktan i žilav, mada ima manjih sočiva trošnog i mekanog zemljasto-detritusnog uglja. Strukture je trakaste, delimično sočivaste, braon do mrke boje, ogreba mrkog, kose i sočivaste slojevitosti, nepravilnog preloma.

Pri stajanju i skladištenju ugalj gubi vlagu, tako da ukupan gubitak vlage pri dužem lagerovanju iznosi i do $24 \%$, tako da se ne može vremenski duže lagerovati, osim pod specijalnim uslovima.

Petrografskim ispitivanjima utvrđeno je da ugalj pripada vitritsko-klaritskom i klaritskom tipu, a sastavljen je od vitrita, klarita, durita i fasita. Usled prilično niskog stepena gelifikacije preovlađuju drvenaste komponente vitrita, koje se kreću od 11 do $35 \%$ i klarita od 37 do $70 \%$, dok je ditrita znatno manje od 3 do $10 \%$.

Anorganske primese u uglju predstavljene su singenetskim terigenim sastojcima, zastupljeni ugljevitim glinama od 9 do $61 \%$, a od autigenih minerala u uglju se nalaze pirit, markasit i siderit, gde je najviše zastupljen pirit od 1 do $5 \%$. Od epigenetskih sastojaka u ovom uglju je jedino zastupljen gips.

$\mathrm{Na}$ osnovu ovih petrografskih analiza ugalj iz revira rudnika "Bajovac" pripada grupi tvrdih mrko-lignitskih ugljeva.

Laboratorijska ispitivanja hemijskotehničkih osobina rovnog uglja iz krovinskog $A_{1}$ sloja uzetog iz jame rudnika „Bajovac“ pokazale su sledeće rezultate:

\section{Tehnička analiza:}

$\begin{array}{lr}\text { - Vlaga } & 35,30 \% \\ \text { - Pepeo } & 16,28 \% \\ \text { - S ukupan } & 1,65 \% \\ \text { - S u pepelu } & 0,59 \% \\ \text { - Koks } & 57,84 \% \\ \text { - C-fix } & 21,36 \% \\ \text { - Sagorljivo } & 48,42 \% \\ \text { - Isparljivo } & 26,86 \% \\ \text { - DTE } & 12.050 \mathrm{~kJ} / \mathrm{kg} \\ \text { - GTE } & 13.574 \mathrm{~kJ} / \mathrm{kg}\end{array}$

Elementarna analiza:

- Ugljenik

- Vodonik

$32,64 \%$

- Kiseonik + Azot

- S sagorljiv
$11,90 \%$

$1,06 \%$ 
Laboratorijska ispitivanja hemijsko-tehničkih osobina rovnog uglja iz krovinskog
$\mathrm{B}_{2}$ sloja uzetog iz radova u reviru Tavnik Strmužak pokazale su sledeće rezultate:

\section{Tehnička analiza:}

$\begin{array}{lr}\text { - Vlaga } & 36,15 \% \\ \text { - Pepeo } & 15,25 \% \\ \text { - S ukupan } & 1,49 \% \\ \text { - S u pepelu } & 0,76 \% \\ \text { - Koks } & 38,83 \% \\ \text { - C-fix } & 23,58 \% \\ \text { - Sagorljivo } & 48,60 \% \\ \text { - Isparljivo } & 25,02 \% \\ \text { - DTE } & 12.050 \mathrm{~kJ} / \mathrm{kg}\end{array}$

Elementarna analiza:

- Ugljenik

- Vodonik

- Kiseonik + Azot

- S sagorljiv

Iz navedenih podataka može se videti da su podaci iz obadva sloja slični, što za ugljeve iz ova dva sloja znači da su praktično isti.

$$
\begin{aligned}
& \text { - Vlaga } \\
& \text { - Pepeo } \\
& \text { - S ukupan } \\
& \text { - S u pepelu } \\
& \text { - Koks } \\
& \text { - C-fix } \\
& \text { - Sagorljivo } \\
& \text { - Isparljivo } \\
& \text { - DTE } \\
& \text { - Ugljenik } \\
& \text { - Vodonik }
\end{aligned}
$$

Takođe su vršeni opiti švelovanja i gasifikacije, gde je utvrđeno da se ugalj iz ovog basena može upotrebljavati za proizvodnju komadnog metalurškog polukoska, koji po dobijenim kvalitetnim osobinama
$70,20 \%$

$5,66 \%$

$22,41 \%$

$1,50 \%$

Kao još jedan podatak iz literature postoji uspešan pokušaj da se ugalj suši parom pod pritiskom od $20 \mathrm{~atm}$. Ovakvo tretiranje je prema podacima dalo odlične rezultate i da je dobijeno gorivo vrlo dobrog kvaliteta i to:

$12,70 \%$

$14,80 \%$

$1,30 \%$

$0,70 \%$

$46,80 \%$

$32,00 \%$

$72,40 \%$

$40,40 \%$

$18.130 \mathrm{~kJ} / \mathrm{kg}$

$50,00 \%$

$4,20 \%$

u potpunosti može zadovoljiti potrebe metalurgije.

Isto tako ugalj se veoma uspešno može primeniti za proizvodnju visokokaloričnog gasa za industrijske i termičke potrebe. 


\section{TEHNIČKO-TEHNOLOŠKI USLOVI EKSPLOATACIJE}

\subsection{KAPACITET PROIZVODNJE}

Kod proračuna kapaciteta proizvodnje u jami rudnika „Bajovac“ treba imati u vidu sledeće činjenice.

1. Tražena proizvodnja od strane Investitora iznosi 200.000 t.k.u.

2. Za otkopavanje uglja mora se predvideti oba ugljena sloja;

3. Na prvom horizontu će se vršiti praktično likvidacija zaštitnih stubova nekadašnjih prostorija otvaranja;

4. U jami bi se primenilo četiri metode otkopavanja, od kojih je samo jedna imala primenu u ovom rudniku.

\section{Kapacitet proizvodnje u I horizontu $(k+240-k+160 m)$}

U krovinskom ugljenom sloju $A_{1}$ u I horizontu zahvatiće se svega $112.000 \mathrm{t}$ geoloških rezervi ili cca 100.000 t.k.u. Rezerve uglja će biti u likvidaciji i primenjivala bi se otkopna metoda koja je već bila u primeni u ovoj jami, a to je modifikovana stubno-komorna metoda. U ovakvim uslovima ne može se očekivati godišnja proizvodnja na nivou većem od 50.000 t.k.u.

S obzirom na karakteristike podinskog ugljenog sloja (moćnost ugljenog sloja od 3 do $12 \mathrm{~m}$ sa učešćem uglja u sloju (u tri tanja sloja) od $50 \%$ tj. od 1,5 do $6,0 \mathrm{~m}$. Zbog veće količine jalovine u uglju otkopanom u ovom sloju, proizvodnja iz ovog sloja ne sme preći $30 \%$ od ukupne proizvodnje pa se u ovoj fazi može planirati proizvodnja od ukupno 20.000 t.k.u.

Ukupna proizvodnja u I horizontu iznosiće u toku prve dve godine 70.000 t.k.u./ god. Ovakvom dinamikom prizvodnje pojaviće se neujednačenost, zato što će se posle dve godine otkopati sav ugalj u krovinskom sloju ovog horizonta i samo do $10 \%$ rezervi u podinskom. Ovaj disbalans će se ispraviti tokom kasnije eksploatacije, kada će se bitno povećati proizvodnja u krovinskom sloju.

\section{Kapacitet proizvodnje u II horizontu $(k+160-k+80 \mathrm{~m})$}

U krovinskom ugljenom sloju $A_{1}$ u II horizontu zahvatiće se 829.000 t geoloških rezervi ili cca 790.000 t.k.u., ali bi se otkopavanje organizovalo sa jednim međuhorizontom, koj bi po visini podelio ovaj horizont na dva jednaka dela. U gornjem međuhorizontu bi bilo cca 340.000 t.k.u. Od ove količine u južnom krilu bi se nalazilo cca 130.000 t.k.u. gde bi se primenjivala otkopna metoda koja je već bila u primeni u ovoj jami. Godišnji kapacitet bi bio 65.000 t.k.u. i otkopavanje bi trajalo 2 godine. Istovremeno bi se u severnom krilu uvelo otkopavanje frikcionim stupcima, koji bi zahvatio cca 210.000 t.k.u. Sa kapacitetom od 80.000 t.k.u. otkopavanje bi trajalo nešto preko 2,5 godine. Deo rezervi uglja će biti u likvidaciji nekadašnjih zaštitnih stubova prostorija otvaranja (cca 40.000 t.k.u.) i primenjivala bi se otkopna metoda koja je već bila u primeni u ovoj jami, a to je modifikovana stubno-komorna metoda. $U$ ovakvim uslovima ne može se očekivati godišnja proizvodnja na nivou većem od 50.000 t.k.u. tako da bi u gornjem međuhorizontu otkopavanje ukupno trajalo 2,5 godina, pri čemu bi se iskopalo cca 380.000 t.k.u. U drugom međuhorizontu bi bilo cca 400.000 t.k.u. Kako u ovom delu nema likvidacija starih zaštitnih stubova, ovaj međuhorizont bi se podelio na dva asimetrična krila i to južno u dužini od $420 \mathrm{~m}$ i severno u dužini od $510 \mathrm{~m}$. Od ukupne količine rezervi u ježnom krilu bi se nalazilo cca 180.000 t.k.u. gde bi se primenjivala otkopna metoda koja je već bila u primeni u ovoj jami. Godišnji kapacitet bi bio 65.000 t.k.u. i otkopavanje bi trajalo cca 3 godine. Istovremeno bi se u severnom krilu uvelo otkopavanje frikcionim stupcima, koji bi zahvatio cca 220.000 t.k.u. Sa kapacitetom od 80.000 t.k.u. otkopavanje bi trajalo 
takođe cca 3 godine, pri čemu bi se iskopalo cca 400.000 t.k.u.

Kako smo rekli da proizvodnja iz podinskog sloja ne sme preći $30 \%$ od ukupne proizvodnje pa se u ovoj fazi može planirati proizvodnju od ukupno 234.000 t.k.u. ili cca 42.000 t.k.u. godišnje.

Ukupna proizvodnja u II horizontu iznosiće u toku 5,5 godine 167.000 t.k.u./god. Ovakvom dinamikom prizvodnje delimično bi se ispeglala neujednačenost, zato što bi se posle 5,5 godina otkopalo oko 260.000 t.k.u. u podinskom sloju I horizonta i cca 40.000 t.k.u. u podinskom II horizonta.

\section{Kapacitet proizvodnje u III horizontu $(k+80-k \pm 0 m)$}

$\mathrm{U}$ krovinskom ugljenom sloju $\mathrm{A}_{1} \mathrm{u}$ III horizontu zahvatiće se 856.000 t geoloških rezervi ili cca 810.000 t.k.u. Rezerve uglja su u idealnom položaju i posle 5,5 godina može se uvesti savremena otkopna metoda, a to je otkopavanje širokočelnim mehanizovanim kompleksom. U ovakvim uslovima može se očekivati godišnja proizvodnja na nivou većem od 180.000 t.k.u. Otkopavanje bi se odvijalo u celom ležištu u dužini od $940 \mathrm{~m}$ i trajalo bi 4,5 godina ili sa prosečnim napredovanjem fronta od $22 \mathrm{~m} / \mathrm{mesec}$.

Proizvodnja iz podinskog sloja ni $u$ ovom horizontu ne sme preći $30 \%$ od ukupne proizvodnje pa se u ovoj fazi može planirati proizvodnja od ukupno 60.000 t.k.u. ili za 4,5 godina 270.000 t.k.u., tako da bi se praktično ostvarilo kašnjenje otkopavanja u podinskom sloju za jedan celi horizont.

\section{Kapacitet proizvodnje u IV horizontu $(k \pm 0-k-80 \mathrm{~m})$}

Poluhorizont (k-80 - k-100 m)-Likvidacija

U ovom poluhorizontu bi se vršilo $u$ krovinskom sloju otkopavanje modifikovanom stubno-komornom metodom sa kapacitetom od 2 x 50.000 t.k.u. dvokrilno i trajalo bi cca 1,5 godina. $\mathrm{S}$ obzirom da bi početkom otkopavanja u ovom poluhori- zontu preostalo oko $450.000 \mathrm{t}$ u krovinskom sloju, isti bi se u ovom slučaju otkopavao u tom periodu na nivou 30.000 t.k.u./god., tako da bi ukupna proizvodnja u ovom periodu bila 130.000 t.k.u.

Preostalih 400.000 t.k.u. u podinskom sloju bi se moglo otkopavati, ako se nađe tržište ili ako se otvore neki drugi rudnici ovog basena. Nezavisno bi moglo da se organizuje otkopavanje na nivou 2 x 40.000 t.k.u. takođe dvokrilno $\mathrm{u}$ trajanju od 5 godina.

\subsection{DINAMIKA PROIZVODNJE I VEK TRAJANJA}

Prema predloženim tehničkim rešenjima eksploatacija ovog ležišta bi se obavljala 22 godine. Godišnja proizvodnja u ovom periodu kretala bi se od 70.000 t/god. u prvoj i drugoj godini, zatim bi se povećavala sukcesivno narednih šest godina a u devetoj godini je moguće dostići maksimalni kapacitet od 240.000 t/god. koji bi se održavao narednih sedam godina. U poslednjih šest godina proizvodnja bi se zbog strukture ležišta polako smanjivala, do poslednje godine eksploatacije kada bi iznosila 40.000 t/god.

\section{ZAKLJUČAK}

Ovaj rad predstavlja izvod iz rezultata istraživanja koja su objavljena u okviru projekta TR 33029 "Izučavanje mogućnosti valorizacije preostalih rezervi uglja u cilju obezbeđenja stabilnosti energetskog sektora Republike Srbije" a koje finasira Ministarstvo prosvete i nauke. U njemu je tretirana problematika buduće eksploatacije uglja iz zapadno moravskog basena, sa posebnim osvrtom na aktiviranje zatvorenog rudnika"Bajovac"

Osnovna ideja kojom su se autori rukovodila je bila da se ovo ležište aktivira kao zamenski kapacitet za Ibarske rudnike do momenta iznalaženja adekvatnijih rešenja. Za analizu mogućnosti eksploatacije uglja iz ovog ležišta korišćena je raspoloživa tehnika dokumentacija uz istovremeno 


\section{LITERATURA}

konsultovanje relevantnih stručnjaka koji su se bavili ovom problematikom.

Veoma detaljna tehno-ekonomska analiza ležišta "Bajovac" nedvosmisleno je utvrdila opravdanost njegovog ponovnog otvaranja. U okviru istraživanja po ovom projektu predložena su osnovna tehnička rešenja otvaranja, metode otkopavanja, potrebna radna snaga po broju i strukturi, potrebna oprema. Ekonomska analiza jedne ovakve investicije koja je obuhvatila troškove, tržište cene i ostale relevantne pokazatelje je takođe dala pozitivne rezultate, pa se stoga može generalno dati pozitivna ocena jednog ovakvog projekta.
[1] N. Vidanović i drugi, Studija opravdanosti eksploatacije u ležištima „Cerje“ Despotovačkog ugljenog basena i „Bajovac“, zapadnomoravskog ugljenog basena, RGF Beograd, 2011.

[2] P. Nikolić, D. Dimitrijević, Ugalj Jugoslavije, Pronalazaštvo, Beograd 1990 ,

[3] N. Vidanović, R. Tokalić, S. Mitić, Opravdanost eksploatacije uglja iz ležišta „Cerje-Jovačko polje“, Časopis „Podzeni radovi”, broj 21, ISSN 03542904, str. 9-15, RGF Beograd, 2012. 